прогресування остеопорозу та персистування анеміі.

\section{ЛITEPATУРA}

1. Kolesnyk $M O$, editor. Natsionalnyi reestr khvorykh na khronichnu khvorobu nyrok ta patsientiv $z$ hostrym poshkodzhenniam nyrok: 2017 rik [National registry of patients with chronic kidney disease and patients with acute kidney damage: 2017]. Kyiv; 2018. 183 p. [In Ukrainian].

2. Melmed S, Casanueva FF, Hoffman AR, et al. Diagnosis and treatment of hyperprolactinemia: an Endocrine

Дата надходження до редакції 23.10.2018 p.
Society clinical practice guideline. J Clin Endocrinol Metab. 2011; 96(2):273-88.

3. Lakshmi D, Meera KS, Mahesh E. Serum prolactin level and inflammation in chronic kidney disease. International Journal of Biochemistry Research \& Review. 2016; 14(1):1-9.

4. Lo JC, Beck GJ, Kaysen GA, et al. Hyperprolactinemia in end stage renal disease and effects of frequent hemodialysis. Hemodial Int. 2017; 21(2):190-196.

https://doi.org/10.24026/1818-1384.4(64).2018.150165

\title{
ПРЕДИКТОРИ РОЗВИТКУ МЕТАБОЛІЧНОГО СИНДРОМУ В ПЕДІАТРИЧНІЙ ПРАКТИЦІ
}

\author{
В.М. Дудник, І.І. Андрікевич, А.В. Хромих, К.В. Хромих \\ Вінницький національний медичний університет ім. М.І. Пирогова
}

За даними ВОО3 метаболічний синдром (MC) $\epsilon$ епідемією 21 століття. Згідно останніх епідеміологічних досліджень серед дітей та підлітків частота МС становить 4-7,6 \%. Точні дані про поширеність цього небезпечного синдрому серед підлітків і дітей молодшого віку практично відсутні та обмежуються лише невеликими відомостями про високу частоту основного його прояву - ожиріння.

Метоюнашоїроботибуло визначенняпредикторів розвитку метаболічного синдрому у дітей віком від 10 до 18 років з метою попередження розвитку ускладнень у даного контингенту.

Матеріали та методи. Проведено ретроспективний аналіз історій хвороб 52 дітей, які проходили санаторно-курортне лікування у Вінницькому дитячому кардіоревматологічному санаторії протягом 2016-2017 рр. У дослідження включались діти віком від 10 до 18 років, у яких діагностовано ожиріння, зумовлене надмірним надходженням енергетичних ресурсів (шифр MKX-10 E 66.0). Ожиріння діагностувалось, коли індекс маси тіла знаходився вище 97 центильного інтервалу відповідно стандартам фізичного розвитку, нині діючим в Україні. Для вивчення предикторів розвитку МС використані критерії, запропоновані IDF Consensus 2007 року (ожиріння, підвищення артеріального тиску (АТ), гіперглікемія). Були використані антропометричні, загальноклінічні (оцінка артеріального тиску), біохімічні та статистичні методи дослідження.

Результати та обговорення: В ході дослідження виявлено, що серед обстежених переважали хлопчики (61,5\%) над дівчатками (38,5\%), що співпадає 3 даними літератури. При цьому у половини обстежених (53,8\%) діагностовано підвищення систолічного та діастолічного АТ, що $€$ одним із критеріїв МС у дітей. При цьому лише у двох обстежених дітей $(3,8 \%)$ діагностовано порушення толерантності до глюкози під час проведення орального глюкозотолерантного тесту. Саме у цієї невеликої когорти дітей виявлено наявність трьох критеріїв, які запропоновані IDF Consensus (2007) для діагностування метаболічного синдрому. Під час виписки усім обстеженим запропоновано програму реабілітації: оптимізація способу життя, підвищення фізичної активності та обов'язкове низькокалорійне збалансоване харчування згідно віку.

Висновки. Таким чином, раннє виявлення предикторів МС у дітей та застосування у них певних профілактичних заходів запобігає виникненню таких ускладнень як цукровий діабет 2 типу, ішемічна хвороба серця, гіпертонічна хвороба, а також інвалідизації в майбутньому. 


\section{ЛІТЕРАТУРА}

1. Наказ МОЗ України від 03.02.09 № 55 «Про затвердження протоколів лікування дітей 3 ендокринними захворюваннями». Додатки.

2. Наказ МОЗ України від 27.04.2006 № 254 «Про затвердження протоколів надання медичної допомоги дітям за спеціальністю «Дитяча

Дата надходження до редакції 09.11.2018 p. ендокринологія». Протокол надання медичної допомоги дітям, хворим на ожиріння.

3. Weiss R. Childhood Metabolic Syndrome Must we define it to deal with it? / R. Weiss // Diabetes Care. 2011. - Vol. 34, N. Suppl. 2. - 171-176.

https://doi.org/10.24026/1818-1384.4(64).2018.150166

\title{
ЕФЕКТИВНІСТЬ МУЛЬТИМОДАЛЬНОЇ АНАЛГЕЗІЇ У ПАЦІЕНТІВ ІЗ ЗАХВОРЮВАННЯМ ЩИТОПОДІБНОЇ ЗАЛОЗИ
}

\author{
О.О. Сфімова, С.О. Тарасенко, М.В. Кунатовський \\ Украйнський науково-практичний центр ендокринної хірургї, трансплантаиії \\ ендокринних органів і тканин МОЗ України
}

\begin{abstract}
Актуальність. Мультимодальна (збалансована) аналгезія $\epsilon$ необхідним компонентом периопераційного анестезіологічного менеджменту для зниження насамперед побічної дії наркотичних (опіоїдних) анальгетиків, яка може заважати швидшому відновленню пацієнтів у післяопераційному періоді.

Збалансована (мультимодальна) аналгезія (ЗММА) передбачає одночасне використання двох або більше анальгетиків, що мають різні механізми дії і дозволяють досягти адекватного знеболення при мінімумі побічних ефектів, властивих призначенням великих доз одного анальгетика в режимі монотерапії.
\end{abstract}

Додавання регіональних методів знеболення (білатеральна блокада поверхневого шийного сплетіння - ББПШС) в комплекс ЗММА дозволяє знизати рівень застосування опіатів та покращити перебіг раннього післяопераційного періоду при виконанні тиреоїдектомій [1].

Мета: Оцінка ефективності комплексу ЗММА на тлі загальної анестезії севофлураном у пацієнтів 3 раком щитоподібної залози, яким виконується тиреоїдектомія в умовах спеціалізованого ендокринологічного центру.

Матеріали та методи. На базі наукового відділу ендокринної хірургії Українського науковопрактичного центру ендокринної хірургії, трансплантації ендокринних органів і тканин МО3 України було включено 96 пацієнтів в дослідження. Комплекс 3ММА включав у себе премедикацію за 25-30 хвилин за принципом pre-emptive analgesia (внутрішньовенне введення дексаметазону 4-8 мг, НПЗП з ліпофільними властивостями декскетопрофену 50 мг) та ББПШС 0,5\% розчином бупівакаїну по 8,0-10,0 мл (40-50 мг) з кожної сторони, а також внутрішньовенне введення метоклопраміду 20 мг. Цей комплекс ЗММА був застосований 47 пацієнтам 3 раком щитоподібної залози, які склали групу збалансованої аналгезії (група 3АС). Групу контролю (група К-С) склали 49 хворих 3 раком щитоподібної залози, яким виконувались тиреоїдектомії за традиційною в клініці методикою анестезіологічного забезпечення без застосування ББПШС та введення НПВП до розрізу. Оперативні втручання виконувались вумовахзагальноїанестезії із ШВЛ у вигляді низько-потокової інгаляційної анестезії севофлураном в групі К-С та мінімальнопотокової інгаляційної анестезії в групі ЗА-С. Аналгетичнийкомпонентзабезпечувавсявведенням фентанілу. Традиційна методика анестезіологічного забезпечення в групі К-С включала премедикації шляхом внутрішньом'язового введення 1,0 мл Омнопону $3 \mathrm{H} \quad 3 \quad 1 \%$ розчином димедролу 1,0 мл за 30-40 хвилин до початку операції; 3 антиеметичною метою на початку операції призначали метоклопрамід внутрішньовенно в дозуванні 10 мг. В післяопераційному періоді в групі ЗА використовувалось знеболення за принципом preventive analgesia [2]: внутрішньовенно вводився декскетопрофен кожні 8 годин протягом 2 діб. Парацетамол або метамізол натрію в дозуванні 1000 мг вводилися внутрішньовенно кожні 12 годин. В групі К застосовувалися морфін 10 мг через 